\title{
Success Factors for Digital Sales Development in B2B Sales of Products Requiring Explanation
}

\author{
Jörg Bothe ${ }^{1}$, Pablo Valentin Weiss ${ }^{2}$ and Bianca Ioana Trifan ${ }^{3}$ \\ 1)2)3) Bucharest University of Economic Studies, Bucharest, Romania. \\ E-mail: joerg.bothe@gmx.de; E-mail: pablo.weiss@gmx.de \\ E-mail: bianca.dumitr@gmail.com
}

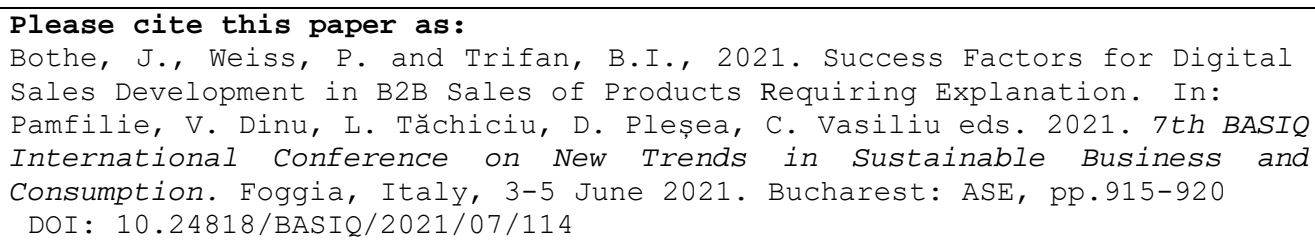

\begin{abstract}
The article focuses on the strategic-operational success factors that make digital sales development possible. For this purpose, different elements are combined into a structured approach. The individual elements look at the opportunities as well as the risks of digitalisation in business-to-business sales with products that need to be explained.
\end{abstract}

\section{Keywords}

Digitalization, B2B Sales, Sales Management, Sales Development, Success Factors.

DOI: $10.24818 / B A S I Q / 2021 / 07 / 114$

\section{Introduction}

The current situation of increasing international competitive pressure, technological change and disruptive market changes make it essential for companies to adapt to the changed environment as quickly as possible (Marquardt, et al., 2018). The changes are not only limited to companies, but also encompass sustainable development in society as a whole (Feroz, 2021). In most companies, the key result driver here is sales, especially in the business-to-business (B2B) sector with products that require explanation (Bothe, 2021). For these reasons, the work of sales is facing enormous changes. Firstly, digitalization opportunities in sales must not be overlooked; secondly, caution is advisable in the resultsensitive area of sales in order to avoid long-term collateral damage. The requirements due to the special characteristics of a digitalisation process are very high. Many companies fail in solving problems not only due to the technical requirements, but also in the permanent implementation in the daily business. These special requirements, combined with the high impact on results of a failed process in result-sensitive sales, make a structured and fast process all the more necessary (Mingaleva, et al.). Digitalisation in sales requiring explanation can not only influence existing processes and organisational forms, it can also change the entire business model of the company. (Rachinger, et al. 2018) The focus should not only be on externally visible changes such as different office or team organisations of large successful digitalisation winners such as Apple, Google, Facebook.

\section{Literature Review}

Success in selling products that require explanation requires a close personal relationship between sales and customers. In combination with technical competence, this results in different positioning for success, with all implications on results. (Grimm, 2001, Bothe, 2019, Mingelva, et al.). Efficient and successful sales management takes into account the most important success factors in sales (Bothe 
2019) and result options as the most important starting points for the orientation of the digitalisation strategy. (Bothe, 2020) Concentrating on the latest app or software programmes also obscures the view of the importance of a highly developed strategic corporate management that understands sales as the core of value creation (Grab, Olaru and Gavril, 2019) (Ritter, 2019). The creation and use of new digital opportunities changes the competitive opportunities through greater degrees of freedom for the company and therefore its business strategy (Kurtz, et al. 2021,).

\section{Research Methodology}

The present topic identifies the success factors for successful digital sales development in the B2B sector. The study refers to the goal of sales development using digital technologies, i.e. focused on strengthening sales success and not on specific technology itself (Ritter and Pedersen, 2019). In addition, the study highlights the important aspect of risks associated with digitalisation, for example with regard to the possible loss of the current sales positioning and the resulting business consequences. The article based on a desk based literature review.

\section{Success factors for digital sales development in B2B sales of products requiring explanation}

In the sale of products and services that require explanation, customer confidence in the performance of the offering company is of decisive importance. An important decision criterion for customers is that the solution offered is also the best possible fit for the customer's existing problem. A technical solution that has a considerable positive differentiation potential compared to competitors and can be communicated to the customer by the sales department is of decisive importance in the operative business. If the technical differentiation potential of the company is low compared to competitors, the sales positioning, the options for action that have an effect on results and the three sales success factors become all the more important. (Bothe, 2019)

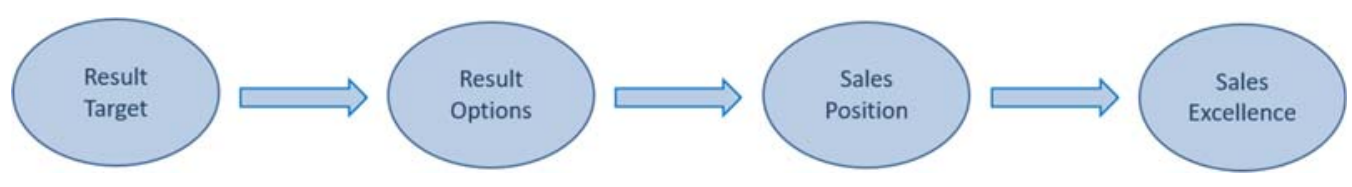

Figure no. 1. Strategy Sales Development in B2B Sales of products requiring explanation Source: Authors' own work

\section{Result-oriented Options for Action}

Ensuring the success of the entire organisation is the most important task of sales management. A profit-oriented sales development strategy must therefore be based on one or more result factors. (Bothe, 2020, p. 117) The profit equation offers the right options for action for sales and a possible complete or partial digitalisation for the envisaged goal of change.

$$
\text { Profit }=\text { Turnover }- \text { Costs }
$$

\section{Equation 1: Profit}

This equation is composed of the factors: quantity, price, costs and contribution margin, as the difference between price and costs. Another option for action is operational excellence, which includes the key success factors of sales management. (Bothe, 2019) 
Quantity

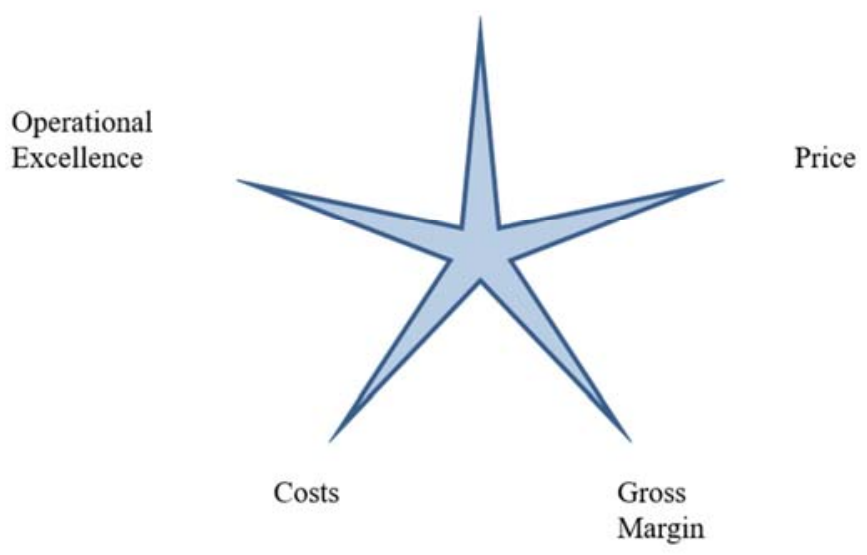

Figure no. 2. Result oriented action opportunities

Source: Bothe, 2020

A sales development needs a clear result target, no matter if it is a full digitalisation, a partial digitalisation (hybrid sales) or a pure analogue one. In choosing a fully digital or hybrid sales approach, sales leader must consider worthwhile scaling effects and take into account the use of (partial) digitisation while weighing the associated risks (Weiss and Grab 2020). The next step is to decide which result-oriented factor should be expanded to achieve this goal. Increasing volume requires a different approach than a pure price strategy. Better customer retention or up-selling programmes to increase the contribution margin also require differentiated approaches. Relative to the number of employees, sales is a significant cost factor. A result target can therefore also be to achieve the same turnover with lower sales costs. The considerable influence that sales also has on costs in the company, e.g. through the information quality of the order forecast, is an independent result-oriented option for action. The selection of the strategy and the options for action then determines the operational implementation and the selection of the digitalisation techniques. (Bothe, 2021)

\section{Sales Positioning}

Every sales organisation with products that require explanation has a certain positioning in relation to customer proximity and technical competence. The matrix formed from these two factors creates the possibility for sales management to compare the desired positioning with the actual positioning of individual salespersons, technical or regional sub-organisations and to initiate the appropriate measures to develop the relevant people (Grimm, 2001).

Essentially, it is necessary to recognise which of the four quadrants is or should be used to sell successfully. Each of the four positioning opens up the possibility for the company to be successful and profitable, but it must fit the overall strategy of the company. In B2B sales of products that need to be explained, it goes without saying that close customer contact is necessary in order to be able to offer and sell one's own technical advantages to the customer. The most sought-after sector here is best technical solution. In connection with the key success factors of sales management, it should be pointed out in particular how important it is to link these success factors with the desired positioning of sales performance in the market. If not completely considered and implemented in operational sales, there is a danger of slipping into the price sector. In practice, however, this alignment takes place too rarely, with corresponding problems in sales and in the company (Bothe, 2019). 


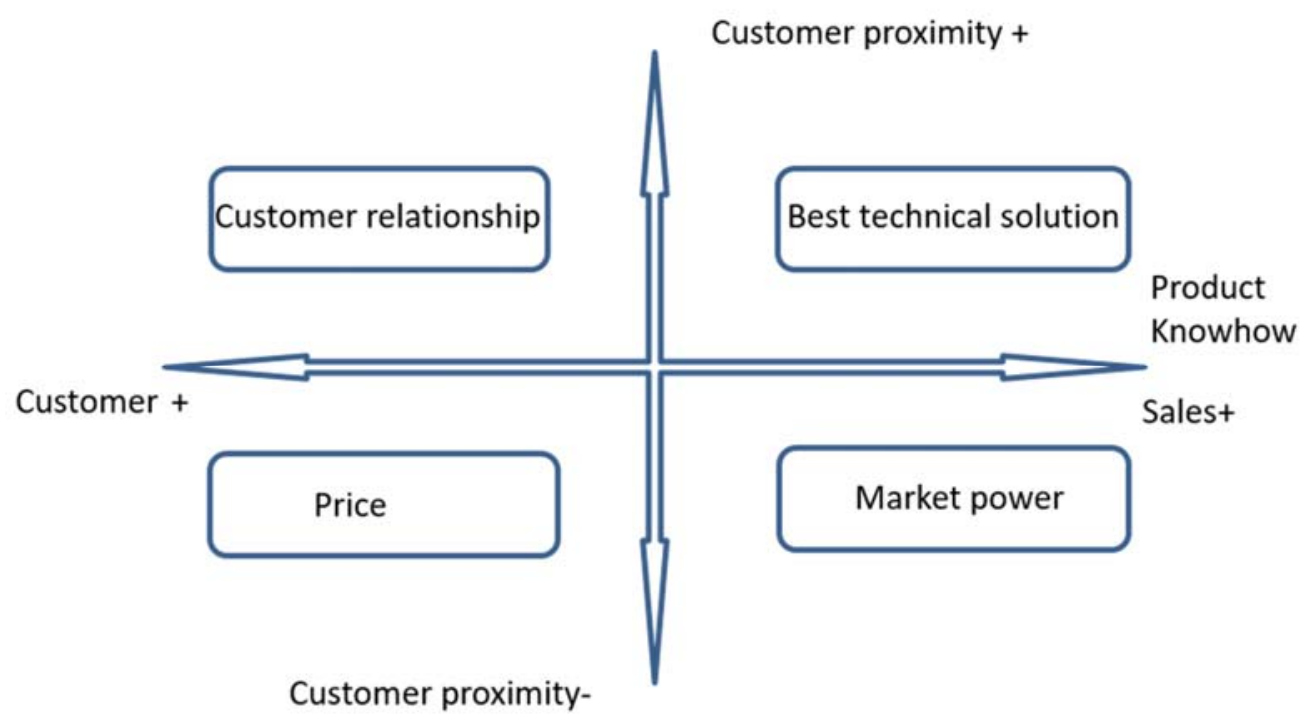

Figure no. 3. Positioning Matrix of B2B-Sales with products that requires explanation Source: Bothe, 2019, according to Grimm, 2001

Once a positioning has been taken, it can change because of competitive dynamics, or changes in the company itself that have not been fully thought through. One reason can be digitalisation in sales, especially if this affects the personal proximity to the customer. Customer increase their product knowhow with each project and thus increase the pressure on companies own competence considerably. Furthermore, customers are increasingly trying to avoid close personal relationship between internal and external persons.

\section{Sales Management Success Factors}

In order to manage a sales department safely and successfully in daily business, it is important to know the success factors for sales success and to recognise the absence of these success factors. In order to do justice to the complexity of the demands placed on a sales department, it is crucial to identify universally valid success factors. The complexity of the task is determined by the role as information and knowledge mediator between independent organisations (Schmitz and Rader 2010; Verbeke, Dietz and Verwaal, 2010; Bothe, 2019).

The Sales Management Key Success factors are the three elements of time, information and motivation. These three factors are complex and mutually dependent. The connection to the complexity of the task of sales to ensure the utilisation of the company and the necessary cash flow makes it necessary to define the key success factors on a high level of abstraction. (Bothe, 2019)

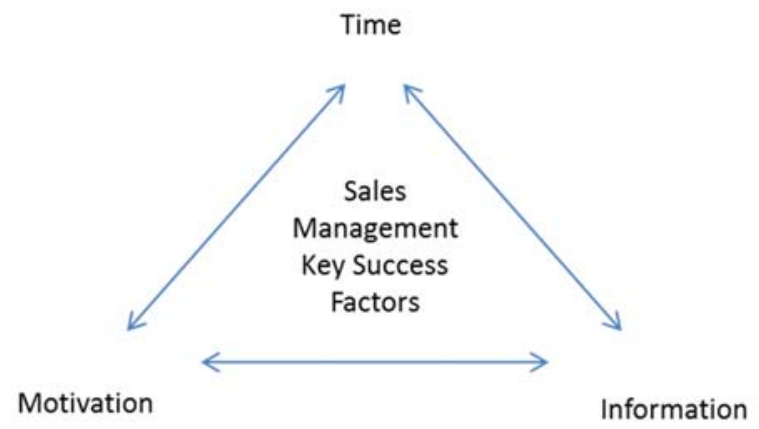

Figure no. 4. Sales Management Key Success Factors triangle Source: Bothe, 2019 


\section{Results and Discussion}

The work shows that in the current digitalisation projects in $\mathrm{B} 2 \mathrm{~B}$ sales of products requiring explanation, which are primarily concerned with the automation of existing processes, simple and clear procedures are sufficient to be successful. The four step process Result Target, Result Options, Sales Position, Sales Excellence. The four-step process is a simple and effective tool to consider the opportunities and risks in a digitisation process from the beginning and to lead the project to success. Not only are the operational and positioning factors taken into account, but also the strategic orientation towards result-oriented options for action. It is foreseeable that this phase will no longer be sufficient at the latest with the establishment of low-cost and simple artificial intelligence systems. Digitalisation in sales has only just begun and a human-less sales department with independently automating sales processes is no longer unimaginable.

\section{Conclusion}

The strategic process for successful digital sales development runs in four stages and looks at the opportunities as well as the risks. A challenging clear result target is set at the beginning to ensure the selection and alignment of options for action to achieve the result target. The resulting activities depend on the current and future sales positioning. This is also important in order not to run the risk of an undesired shift in the targeted and goal-oriented sales positioning. Furthermore, it is important to observe the generally valid key success factors for successful sales in order to reliably achieve the goal in operational sales management as well.

\section{References}

Bothe, J., 2019. Sales Management Key Success Fators in a Complex Environment. Romanian Economic and Business Review, 14(1), pp. 7-14.

Bothe, J., 2019. Wachstumsmotor Positionierung, White Paper, Ergebnisschmiede Band 2, pp.7 [online] Available at: <https://joerg-bothe.de/band_2_wachstumsmotor_final/> [Accessed 29 April 2021].

Bothe, J., 2020. Führungskultur und Supportive Leadership - Nur Vertrauen und Respekt führen zu Höchstleistungen. Wiesbaden: Springer Fachmedien Wiesbaden GmbH.

Bothe, J., 2021. Das Prinzip des Vertriebserfolgs, White Paper, Ergebnisschmiede Band 4, pp.5. [online] Available at: $<$ https://joerg-bothe.de/band_4_prinzip_des_vertriebserfolgs/ $>$ [Accessed 30 April 2021].

Feroz, A.K., Zo, H. and Chiravuri, A., 2021. Digital Transformation and Environmental Sustainability: A review and Research Agenda. Sustainability 2021, 13(3), Article number: 1530.

Fogorș, T.E, Maftei, M., Olaru, S.M. and Bițan, G.E., 2020. From traditional to digital: A study on business models in the context of digitalization. In Mihaela Alina Dima ed, Proceedings of the 3rd International Conference of Economics and Social Scienses Innovative Models to Revive the Global Economy, Ed. Sciendo, 2021, pp. 749-758.

1. Grab, B., Olaru, M., Gavril, R., 2019. The Impact of Digital Transformation on Strategic Business Management. Ecoforum Journal, 1(18), pp.1-8.

Grimm, P., 2001. Der verratene Verkauf. Offenbach am Main: Gabal Verlag.

Kurtz, H., Hanelt, A. and Kolbe, L.M., 2021. Exploring Strategic Orientations in the Age of Digital Transformation: A Longitudinal Analysis of Digital Business Model Patterns Proceedings of Wirtschaftsinformatik [online]

Available

at: $<$ https://aisel.aisnet.org/wi2021/HDigitaltransformation17/Track17/2> [Accessed 03 May 2021]. 


\section{BASIQ INTERNATIONAL CONFERENCE}

2. Marquardt, K., Olaru, M., Golowko, N. and Kiehne, J., 2018. In Pamfilie, R; Dinu, V; Tachiciu, L; Plesea, D; Vasiliu, C. eds. Basiq International Conference: New Trends in Sustainable Business and Consumption. Book Series: Proceedings of BASIQ, Pages: 65-73.

3. Mingaleva, Z., Kostyreva, A., Shironina, E. and Dvinskikh, K., 2021. Organizational Capacity Assessment Model for Digital Transformation. In: T. Antipova, ed. Advances in Digital Science. Cham: Springer International Publishing.

4. Rachinger, M., Rauter, R., Müller, C., Vorraber, W. and Schirgi, E., 2019. Digitalization and its influence on business model innovation. Journal of Manufacturing Technology Management, 30(8), pp.1143-1160.

5. Ritter, P., 2019. Digitization capability and the digitalization of business models in business-tobusiness firms: Past, present, and future, [online] Available at: $<$ https://www.sciencedirect.com/science/article/pii/S0019850119300999> [Accessed 29 April 2021].

6. Schmitz C., Rader, P., 2010. Sales Complexity - Conceptualization and a new measure of complexity. In AMA Winter Educators 2010 Conference, New Orleans, Lousiana.

7. Verbeke, W., Dietz, B. and Verwaal, E., 2010. Drivers of sales performance: a contemporary meta-analysis. Have salespeople become knowledge brokers, [online] Spingerlink.com. Available at: $<$ https://link.springer.com/article/10.1007/s11747-010-0211-8> [Accessed 29 April 2021].

8. Weiss, P. and Grab, B., 2019. Risks and opportunities of digital platforms for scaling business models. In Pamfilie, R; Dinu, V; Tachiciu, L; Plesea, D; Vasiliu, C, eds. Proceedings of BASIQ International Conference on New Trends in Sustainable Business and Consumption, Messina, Italy, 2020. Editura ASE. 